\title{
HIV-1/2 RNA Measurement
}

National Cancer Institute

\section{Source}

National Cancer Institute. HIV-1/2 RNA Measurement. NCI Thesaurus. Code C161393.

The determination of the amount of HIV-1/2 RNA present in a sample. 